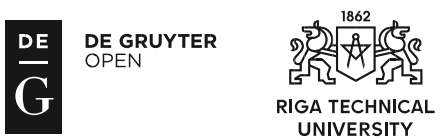

ISSN 2256-0394 (online)

ISSN 2256-0386 (print) 2018, 32, 112-125

doi: 10.2478/eb-2018-0009

https://www.degruyter.com/view/j/eb

\title{
IMPACTS OF MACRO ECONOMIC VARIABLES ON THE RMG EXPORT GROWTH OF BANGLADESH
}

\author{
Afroza Ahammed SHIMU ${ }^{1}$, Md. Shahidul ISLAM ${ }^{1,2}$ \\ ${ }^{1}$ Bangladesh Knitwear Manufacturers \& Exporters Association (BKMEA), Dhaka, \\ Bangladesh \\ ${ }^{2}$ Bangladesh Institute of Social Research (BISR) Trust, Dhaka, Bangladesh \\ Corresponding author's e-mail: shahidulsoc@gmail.com
}

\begin{abstract}
The ready-made garments (RMG) sector of Bangladesh is considered as a key driver for the Bangladeshi Economy. This paper tries to examine the impacts of macroeconomic variables on the RMG export growth of this country. For this purpose, secondary data was collected from various sources. Multiple linear regression model was applied to measure the effects of macroeconomic variables on the RMG export growth. Trade Entropy and the Competitiveness Index were applied to understand the status of RMG sector in the world market. After that, to check the accuracy of the regression model, three types of econometric problems were tested in this study. Firstly, heteroscedasticity problem was tested by graphical presentation. Secondly, auto-correlation problem was tested by Durbin Watson test. Thirdly, multicollinearity problem was tested by correlation matrix and Variance Influence Factor (VIF). The empirical results show that for every unit increase of the growth rate of official exchange rate, inflation rate, real interest rate, and female unemployment rate; the growth rate of RMG export decreases by $1.159,0.055,0.034$, and 0.068 units, respectively.
\end{abstract}

Keywords: Econometric problems, ready-made garments, macroeconomics, Bangladesh.

JEL Classification: C01, E00, L16

\section{INTRODUCTION}

Bangladesh has been recognized as a successful country in terms of export growth, especially the export of RMG products over the last two decades. The GDP growth raised from $3 \%$ to $7.05 \%$ during 1970-2017. Bangladesh government has been implementing trade liberalization and export promotion policy since 1980. At that time, policies were implemented, which included special incentives to exportoriented industries, reducing regulation and control related to tariffs, encouraging private investment. These policies played crucial role to increase the competitiveness of this sector in international market (Al Mamun \& Nath*, 2005). These comprehensive trade reforms changed the scenario of macroeconomic instability and caused export boom in the 1990s (Hossain \& Karunaratne, 2004). 
From that time, the RMG sector had emerged as a leading export earning sector and started to earn significant amount of foreign currency under the asylum of the Multi-fiber Arrangement (MFA) and WTO Agreement on Textile and Clothing (ATC). The liberalized import policy through successive reduction in tariff rates and phasing out of quantitative restrictions help this sector to be recognized as the major export earning sector of Bangladesh. Although, Bangladesh was considered as least developed country (LDC) since 1975, recently Bangladesh has been recognized as a lower middle-income country according to the World Bank's estimation of gross national income per capita (GNI). The successive export performance of this sector since 1980s helps the country to achieve this prestigious recognition in the world economy.

The RMG sector is not only the major earning source of foreign currency but also plays a crucial role in socio-economic development by creating employment, women empowerment and poverty alleviation (Khan \& Rodrigues, 2015). Despite many problems and difficulties such as natural disasters, poor infrastructure, weak governance and political conflict, this sector has been positively contributing to ensure robust economic growth, social commitment, and competitive efficiency (Bhattacharya, Rahman, \& Raihan, 2002).

The share of RMG export to total export rose from 0.5 percent in 1980-1981 to $82.01 \%$ in $2015-2016$. Thereafter, RMG export increased by more than 15 percent per annum on average during the last 15 years. This sector is targeting to earn 50 billion dollars by 2021. Currently, this sector contributes more than 10 percent to the national economy and creates employment for more than 4.4 million people, 80 percent of them are women (BGMEA, 2017).

RMG sector of Bangladesh is divided in two broad categories such as wovens and knits. The knitwear sector has been increasing since the early 1990s (Shimu \& Islam, 2016). In terms of export, the knitwear sector is one of the leading export earning sectors of Bangladesh. Additionally, this sector has global competitiveness in terms of product quality and price through industrial up-gradation, usage of latest machinery, vertical integration, and industrial agglomeration. This sector is also concerned to environmental degradation, use of energy-efficient technology, and renewable energy technology (Reza, Islam, \& Shimu, 2017).

RMG sector of Bangladesh is basically considered as a labour-intensive sector. In Bangladesh, labour is cheaper than in other competitive countries and this cheap labor force is the major basis of comparative advantage. The availability of cheap labour force and strong backward linkages help this sector to take the position of largest exporter in Asia, and second largest exporter in world just after China. This paper examines the effects of macroeconomic variables on the growth of RMG export, as well as the challenges and opportunities from macroeconomic perspective. Besides, this paper investigates the position of Bangladesh RMG export in the world market. 


\section{REVIEW OF LITERATURE}

\subsection{Impact of Export Growth on GDP Growth}

Chow (1987) investigates the relationship between export growth and industrial development in eight Newly Industrial Countries (NICs). He finds a bidirectional causality between export growth and industrial development in these developing countries. Al Mamun and Nath (2005) examined the relationship between export growth and economic growth of Bangladesh. They find a long-run unidirectional causality relation between export growth and economic growth during1976-2003. Another study states that investment in GDP share increases the growth rate of GDP in normal years (Begum \& Shamsuddin, 1998). Hossain and Karunaratne (2004) investigated the relationship between positive export growth and economic growth of Bangladesh during the period 1974-1999. They found that positive relationship exists between manufacturing export and total export. Similarly, another study reveals that manufacturing export is the dominant determinant of the export-led growth of Bangladesh.

Kabir Hassan and Tufte (1998) examine the long-run and short-run determinants of Bangladesh export growth. These determinants are world trade volume, price of export good, and exchange rate volatility. They find that export growth of Bangladesh is negatively related to the volatility of Bangladeshi exchange rate.

Ahmed and Uddin (2009) illustrate that export, import, and remittance affect the GDP growth in the short-run, but there is no long run consequences. Moreover, they explore that long-run GDP growth causes short-run unidirectional income growth. Their findings suggest that real GDP, real exports, real imports and real remittance are co-integrated and there exists long-run relationship among these variable.

\subsection{Trade Liberalization in Terms of Exchange Rate}

Dawson (2006) examines the relationship among export growth, import growth, and income growth of Bangladesh after trade liberalization period. He finds that about $1.15 \%$ export shock or import shock can increase or decrease GDP by about $0.40 \%$, but a shock in GDP has no significant impact on long-run export or import. He also reveals that trade liberalization increases the export growth but there is no significant long-run impact on export-import relationship. Cushman (1983) investigates the effect of exchange rate risk on international trade. He finds that an unanticipated change in exchange rate is risky for international trade. M. A. Hossain and Alauddin (2005) suggest that trade liberalization has had a positive impact on the export growth of Bangladesh. They find that real GDP experienced steady growth in the 1990s, which is known as the post-liberalization period. According to this study, the overall export is highly concentrated on certain commodities, especially on textile and ready-made garments. This study reveals that lack of product diversification and market diversification may create serious vulnerability to this sector. Aziz (2008) suggests that the real exchange rate has a significant impact on trade balance of Bangladesh. Additionally, the granger 
causality test affirms the causal relationship between exchange rate and trade balance of Bangladesh. The Impulse Response Function (IRF) also supports the positive impact of real effective exchange rate on trade balance in the long-run. Moreover, this study reveals that devaluation or depreciation of exchange rate is positively related to the improvement of trade balance.

Andersson and Styf (2010) examine the effect of exchange rate depreciation on trade balance. They find that depreciation of real effective exchange rate increases the trade ratio immediately, but decreases over time. Raza, Larik and Tariq (2013) investigates the effect of currency depreciation on trade balances of South Asian countries. They apply the Marshal-Lerner Model, which states that devaluation or depreciation of currency makes exports relatively cheaper and imports relatively expensive. This study supports the outcome of Marshal-Lerner Model that devaluation of currency does not always help in improving trade balance.

\subsection{Interest Rate, Investment and Inflation to GDP}

Ferdousi (2009) investigates the relationship between interest rate and investment in context of Bangladesh. This study finds that income, saving, and exchange rate has significant impact on investment. According to this study, investment friendly environment and efficient financial system are more important than providing low cost fund for increasing investment spending. Muktadir-AlMukit and Shafiullah (2014) investigate the relationship among inflation rate, import volume, and export volume of Bangladesh. They find that one percent increase of import volume contributes to $3.21 \%$ increase of inflation rate but one percent increase of export volume results in $1.91 \%$ decrease of inflation rate. They also reveal that bilateral causality exists between inflation rate and export volume as well as unidirectional causality exists between inflation rate and import volume. Semuell and Teddy (2014) find the positive relationship among inflation rate, interest rate, and GDP of Indonesia.

\subsection{Relationship Between Macroeconomic Variables and the Growth Rate}

Hossain and Islam (2015) investigate the relationship between macroeconomic variables and the growth rate of Bangladesh $\mathrm{RMG}$ export. They find that individually these variables do not have significant impact on RMG export growth, but when these variables are combined, they affect the RMG export growth significantly. Shimu and Islam (2016) find that export trend of Bangladesh RMG sector is upward. Their results reveal that after the phasing-out of MFA and quota protection, the RMG export has increased.

\section{DATA AND METHODS}

This study is based on secondary data collected from different sources such as trade bodies, published books and magazines of government, private institutions and international organizations, Bangladesh Garment Manufacturers and Exporters Association (BGMEA), Bangladesh Knitwear Manufacturers \& Exporters Association (BKMEA), World Bank, International Trade Centre (ITC), working 
papers of research organizations, etc. A desk review of secondary data and documents is conducted to present the overall situation. The macroeconomic data from 1995 to 2014 has been collected from the World Bank (World Bank,2017).

\subsection{Data Analysis}

Statistical Package for the Social Sciences (SPSS) 21 is used to analyze the data. Trade Entropy and the competitiveness index were applied to understand the status of RMG sector in the world market. Graphical presentation (plotting method) was applied to detect the heteroscedasticity problem. Then, Durbin Watson test was applied to test the autocorrelation problem. Further, correlation matrix and Variance Influence Factor (VIF) was also applied to identify the multi-collinearity problem. These three types of econometric problem were checked in regression model, this multiple regression model was applied to examine the impacts of macroeconomic variables on the growth of Bangladesh RMG export.

\subsection{Variables of the Study Used in Regression}

Independent variable: The independent variables of this study are growth rate of GDP(V2), growth rate of official exchange rate(V3), growth rate of inflation (V4), growth rate of real interest rate (V5), female unemployment rate(V6), and growth rate of current account balance (V7).

Dependent variable: The dependent variable of this study is the growth rate of total RMG export (V1).

\section{RESULTS}

\subsection{Trade Competitiveness of Bangladesh RMG Sector}

In this analysis, Trade Competitiveness is used to observe the actual condition of Bangladesh RMG sector in global apparel market. Therefore, Trade Entropy (TE) Index and Competitiveness Index are used to explore the competitive scenario of Bangladesh RMG sector.

\subsubsection{Trade Entropy}

Trade Entropy is a useful tool to measure the geographical concentration or diversification of a country's or region's export. This tool is used to investigate whether or not a country is heavily reliant on a small number of markets to export their product or sell to a diverse range of markets. "The Trade Entropy Index is calculated by summing up the export shares multiplied by the natural log of the reciprocal of export shares (a weight that decreases with the size of the share) of the country under study across all destinations" (Mikic \& Gilbert, 2008). The range of Trade Entropy Index is between 0 and $+\infty$, where higher value indicates the consistency in the geographical scattering of export. 
Mathematical definition:

$$
\sum_{d}\left[\frac{\sum_{s} X_{S d}}{\sum_{s w} X_{s w}}\right] \operatorname{In}\left[\frac{1}{\sum_{s} X_{s d} / \sum_{s w} X_{s w}}\right]
$$

where

$s$ set of source countries under study;

$d$ set of destinations;

$w$ set of countries in the world;

$X$ bilateral flow of exports from the source to the destination. The sets $\mathrm{d}$ and $\mathrm{w}$ contain the same elements.

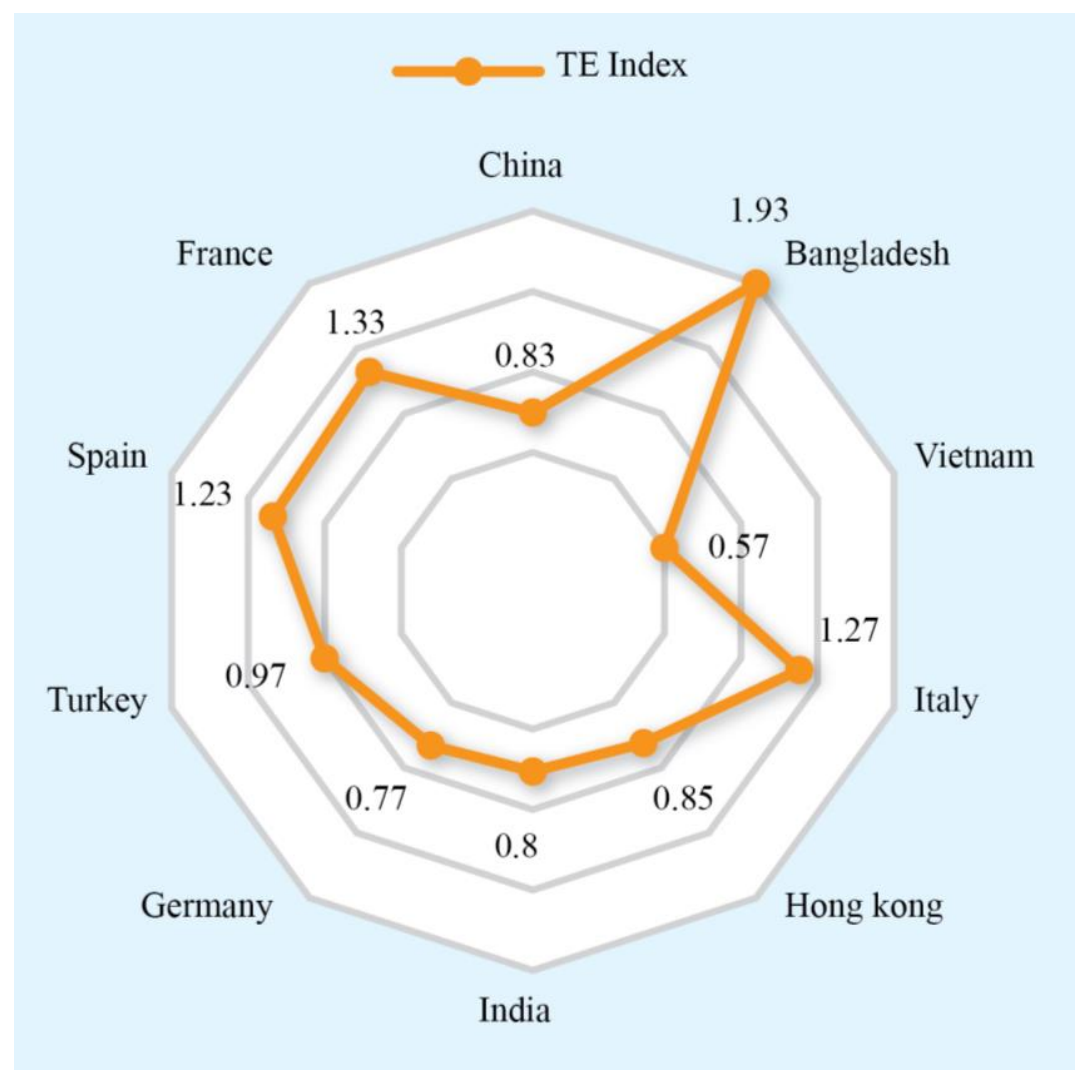

Fig.1. Visual representation of Trade Entropy Index (2015).

Figure 1 shows that in 2015, the Trade Entropy Index of Bangladesh is 1.93, which is the highest comparing with other major RMG exporting countries. This value indicates that export of Bangladesh ready-made garments is geographically more diversified comparing with others. Moreover, Trade Entropy Index for France and Italy are 1.33 and 1.27 , respectively. It reveals that these two countries take the second and third position in case of market diversification. Trade Entropy Index for other countries such as Spain, Turkey, Hong Kong, China, India, Germany, and Vietnam are $1.23,0.97,0.85,0.83,0.8,0.77$, and 0.57, respectively. Noticeably, though China is the world's largest RMG exporting country, Trade Entropy (TE) Index shows a weaker position of this country comparing with Bangladesh. 
Table 1. Trade Entropy for RMG export (2015), value in million USD

\begin{tabular}{|c|c|c|c|c|c|c|c|c|c|c|c|c|c|}
\hline Competitors & China & Bangladesh & $\begin{array}{l}\text { Viet } \\
\text { Nam }\end{array}$ & Italy & $\begin{array}{l}\text { Hong } \\
\text { Kong, } \\
\text { China }\end{array}$ & India & Germany & Turkey & Spain & France & ROW & Total & $\begin{array}{c}\text { TE } \\
\text { Index }\end{array}$ \\
\hline China & NA & 202.44 & 4379.97 & 2871.12 & 6655.02 & 729.52 & 7022.25 & 413.55 & 3631.85 & 4219.59 & 132223.70 & 162349 & 0.83 \\
\hline Bangladesh & 425.72 & NA & 3.18 & 1294.09 & 95.96 & 132.65 & 4784.74 & 751.37 & 2129.48 & 2168.70 & 18729.04 & 30514.93 & 1.93 \\
\hline Viet Nam & 565.69 & 0.11 & 0 & 203.73 & 204.61 & 8.48 & 688.31 & 14.60 & 513.43 & 348.93 & 18886.30 & 21434.18 & 0.57 \\
\hline Italy & 603.33 & 0.60 & 10.47 & NA & 1264.14 & 18.67 & 1846.65 & 215.90 & 1126.16 & 2093.73 & 12205.77 & 19385.41 & 1.27 \\
\hline $\begin{array}{l}\text { Hong Kong, } \\
\text { China }\end{array}$ & $\begin{array}{r}1144.3 \\
5\end{array}$ & 40.56 & 55.48 & 405.17 & NA & 49.90 & 1134.72 & 16.05 & 234.75 & 542.12 & 13822.54 & 17445.64 & 0.85 \\
\hline India & 72.60 & 53.60 & 0.73 & 387.16 & 83 & NA & 1122.30 & 38.34 & 705.89 & 825.16 & 13842.42 & 17131.19 & 0.80 \\
\hline Germany & 115.01 & 0.33 & 4.63 & 808.84 & 103.15 & 6.11 & NA & 94.85 & 659.21 & 1696.61 & 13167.96 & 16656.70 & 0.77 \\
\hline Turkey & 41.63 & 0.13 & 0.21 & 513.85 & 22.04 & 4.01 & 2685.04 & NA & 1627.46 & 723.17 & 9227.66 & 14845.20 & 0.97 \\
\hline Spain & 351.70 & 0.68 & 9.31 & 1228.84 & 73.42 & 33.50 & 787.42 & 322.88 & NA & 1552.12 & 7514 & 11873.87 & 1.23 \\
\hline France & 268.35 & 0.04 & 5.32 & 1225.93 & 435.64 & 6.55 & 991.15 & 48.50 & 1151.64 & NA & 5641.56 & 9774.68 & 1.33 \\
\hline
\end{tabular}

Source: International Trade Centre (ITC) (2017) 


\subsubsection{The Competitiveness Index}

The competitiveness index measures the market power of a country through its export share in the world market. It takes a value between 0 and 100, higher value indicating greater market power of the country and lower value indicating lower market power of that particular country in the world market (Mikic \& Gilbert, 2008).

Mathematical definition:

$$
\frac{\sum_{d} X_{i s d}}{\sum_{w d} X_{i w d}} \times 100
$$

where

$s$ is the country of interest,

$d$ and $w$ are the set of all countries in the world,

$i$ is the sector of interest, and

$X$ is the commodity export flow.

This means that it expresses the share of country's export of product $i$ in the total world export of that product (Mikic \& Gilbert, 2008).

Table 2. Competitiveness index (2016)

\begin{tabular}{|l|r|}
\hline \multicolumn{1}{|c|}{ Exporters } & Competitiveness Index For RMG \\
\hline China & 33.63 \\
\hline Bangladesh & 7.69 \\
\hline Vietnam & 5.66 \\
\hline Italy & 4.58 \\
\hline Germany & 3.93 \\
\hline India & 3.89 \\
\hline Hong Kong, China & 3.42 \\
\hline Turkey & 3.39 \\
\hline Spain & 2.82 \\
\hline France & 2.30 \\
\hline
\end{tabular}

Source: International Trade Centre (ITC) (2017)

The competitiveness index for RMG shows that China, Bangladesh, and Vietnam take the first, second, and third position respectively, among major exporter countries. China shows the maximum ability and highest performance in world apparel market. Bangladesh holds the second competitive position after China.

\subsubsection{Econometric Problems}

Three main econometric problems have been tested here: (a) heteroscedasticity problem; (b)multi-collinearity problem; and (c)autocorrelation problem.

Heteroscedasticity problem. To detect the heteroscedasticity problem plotting method (graphical representation) was used. According to this method, there is no heteroscedasticity problem is this analysis. From this figure, it is clear that independent variables are significant predictors of data. 


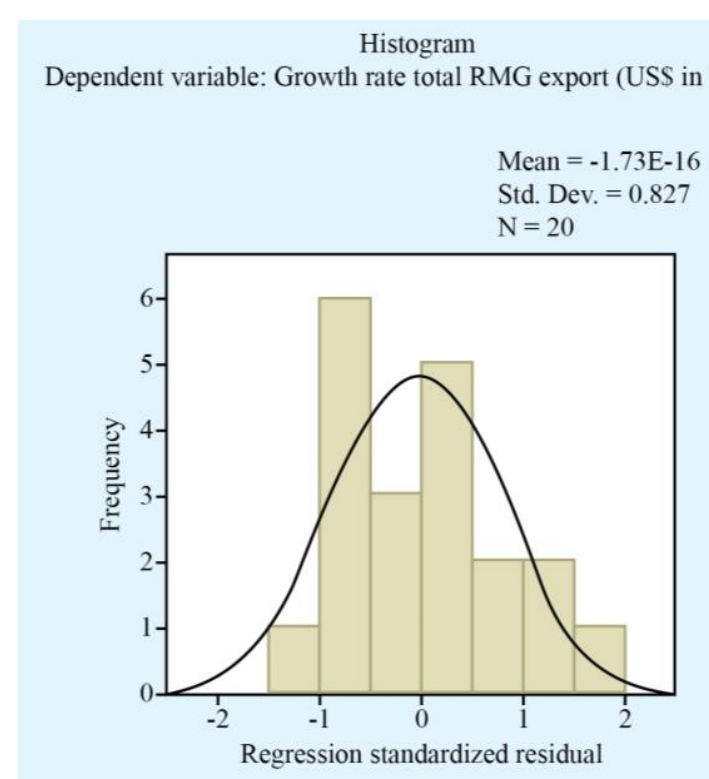

Normal P-P Plot of regression standardized residual Dependent variable: Growth rate total RMG export (USS in billion) Dependent variable: Growth rate total RMG export (USS in billion)
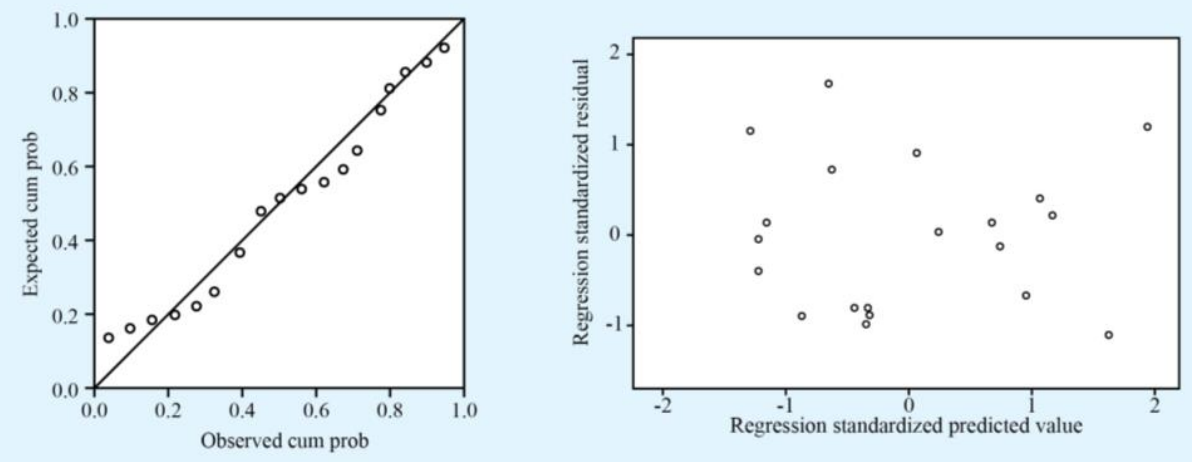

Fig. 2. Detecting heteroscedasticity problem.

Multi-collinearity problem. To detect the multi-collinearity problem, correlation matrix of the macroeconomic variables and RMG export growth are applied in this analysis (Table 3). Correlation matrix shows that small multicollinearity problem has existed here. Further, VIF value is found from 1 to 10 (Table 4). Thus, overall analysis shows no multi-collinearity problem.

Table 3. Correlation matrix of variables

\begin{tabular}{|c|r|r|r|r|r|r|r|}
\hline Variables & \multicolumn{1}{|c|}{ V1 } & \multicolumn{1}{c|}{ V2 } & \multicolumn{1}{c|}{ V3 } & \multicolumn{1}{c|}{ V4 } & V5 & V6 & V7 \\
\hline V1 & 1 & & & & & & \\
\hline V2 & 0.136 & 1 & & & & & \\
\hline V3 & -0.606 & 0.058 & 1 & & & & \\
\hline V4 & -0.171 & -0.208 & -0.242 & 1 & & & \\
\hline V5 & -0.102 & 0.382 & -0.114 & -0.328 & 1 & & \\
\hline V6 & -0.301 & 0.043 & 0.169 & -0.147 & -0.096 & 1 & \\
\hline V7 & 0.0043 & -0.287 & -0.283 & -0.067 & 0.010 & 0.198 & 1 \\
\hline
\end{tabular}


Autocorrelation problem. To detect the autocorrelation problem, Durbin Watson test is used in this analysis. The result of Durbin Watson test is found as 1.836. This result reveals that there is no autocorrelation problem in this analysis.

Table 4. Multiple regression analysis shows the effects of macroeconomic variables on RMG export growth

\begin{tabular}{|c|c|c|c|c|c|c|c|c|}
\hline \multirow[t]{2}{*}{ Model } & \multicolumn{2}{|c|}{$\begin{array}{l}\text { Unstandardized } \\
\text { Coefficients }\end{array}$} & \multirow{2}{*}{$\begin{array}{c}\text { Standardized } \\
\text { Coefficients } \\
\text { Beta }\end{array}$} & \multirow[t]{2}{*}{$\mathbf{t}$} & \multicolumn{2}{|c|}{$\begin{array}{c}95.0 \% \\
\text { Confidence } \\
\text { Interval for B }\end{array}$} & \multicolumn{2}{|c|}{$\begin{array}{c}\text { Collinearity } \\
\text { Statistics }\end{array}$} \\
\hline & B & $\begin{array}{c}\text { Std. } \\
\text { Error }\end{array}$ & & & $\begin{array}{l}\text { Lower } \\
\text { Bound }\end{array}$ & $\begin{array}{l}\text { Upper } \\
\text { Bound }\end{array}$ & Tolerance & VIF \\
\hline Constant & 3.785 & 6.306 & & 0.600 & -9.838 & 17.408 & & \\
\hline $\begin{array}{l}\text { Growth rate of } \\
\text { GDP(V2) }\end{array}$ & 1.616 & 1.109 & 0.248 & 1.457 & -0.780 & 4.011 & 0.741 & 1.350 \\
\hline $\begin{array}{l}\text { Growth rate of } \\
\text { official } \\
\text { exchange } \\
\text { rate(V3) }\end{array}$ & $-1.159 * * *$ & 0.249 & -0.772 & -4.653 & -1.697 & -0.621 & 0.779 & 1.284 \\
\hline $\begin{array}{l}\text { Growth rate of } \\
\text { inflation(V4) }\end{array}$ & $-0.055^{* * * *}$ & 0.018 & -0.511 & -3.066 & -0.094 & -0.016 & 0.772 & 1.295 \\
\hline $\begin{array}{l}\text { Growth rate of } \\
\text { real interest rate } \\
(\%)(\mathrm{V} 5)\end{array}$ & $-0.034 * *$ & 0.012 & -0.479 & -2.796 & -0.060 & -0.008 & 0.729 & 1.371 \\
\hline $\begin{array}{c}\text { Female } \\
\text { unemployment } \\
\text { rate(V6) }\end{array}$ & $-0.068^{*}$ & 0.038 & -0.287 & -1.824 & -0.150 & 0.013 & 0.870 & 1.150 \\
\hline $\begin{array}{c}\text { Growth rate of } \\
\text { Current account } \\
\text { balance }(\%)(\mathrm{V} 7)\end{array}$ & -0.001 & 0.002 & -0.078 & -0.459 & -0.005 & 0.004 & 0.746 & 1.341 \\
\hline
\end{tabular}

$R^{2}=0.721$, and Durbin-Watson 1.836

Significant at $* p>0 \cdot 10 ; * * p>0 \cdot 05 ; * * * p>0 \cdot 01$

Result of multiple regression analysis. The following model reflects the overall result of the multiple regression analysis.

RMG export predicted $=3.785+1.616$ growth rate of GDP -1.159 growth rate of official exchange rate -0.055 inflation rate -0.034 growth rate of real interest rate -0.068 female unemployment rate -0.001 growth rate of current account balance. Therefore, the value of $\mathrm{R}$ Square $\left(\mathrm{R}^{2}\right)$ expresses that the model only explains $72.10 \%$ of RMG export growth.

Growth rate of GDP. According to the result, for every unit increase of the growth rate of GDP, the RMG export growth rate will increase by 1.616 , while other independent variables remain constant. But the $p$-value indicates that this result is not significant.

Growth rate of Official exchange rate. The result indicates that for every unit increase of the growth rate of official exchange rate the RMG export growth rate 
will decrease by 1.159 while other independent variables remain constant. The pvalue indicates that the result is significant.

Growth rate of inflation rate. According to the result, for every unit increase of the growth rate of inflation rate the RMG export growth rate will decrease by 0.055 while other independent variables remain constant. This result is significant.

Growth rate of Real Interest rate (\%). The result reveals that for every unit increase of the growth rate of real interest rate, the RMG export growth rate will decrease by 0.034 while other independent variables remain constant. This result is significant.

Growth rate of female unemployment rate. According to the result, for every unit increase of the growth rate of female unemployment rate the RMG export growth rate will decrease by 0.068 while other independent variables remain constant. This result is statistically significant.

Growth rate of current account balance (BOP, billion US\$). The result shows that for every unit increase of the growth rate of current account balance, the RMG export growth rate will decrease by 0.001 while other independent variables remain constant. But the p-value indicates that the result is not statistically significant.

\section{DISCUSSION}

This study reveals that positive growth of official exchange rate negatively affects the RMG export growth of Bangladesh. Evidence supports that weak currency or lower exchange rate and economic growth are positively related to each other (Di Nino, Eichengreen, \& Sbracia, 2011). This study shows that positive growth of inflation rate negatively affects the RMG export growth. In general, higher inflation rate increases price variability of an economy. It makes profitability of investment projects more uncertain. Consequently, more conservative investment strategies lead to lower levels of investment, which impede economic growth of an economy. In addition, higher inflation rate makes the country's exports relatively more expensive and decreases the export volume which reduces country's global competitiveness (Gokal \& Hanif, 2004). Furthermore, higher investment is encouraged by stable and lower inflation rate, which increases the RMG export. Consequently, the stable inflation rate also increases the price competitiveness of this sector in global market.

This study reveals that positive growth of real interest rate negatively affects the RMG export growth. Higher interest rate makes borrowing money more expensive and it encourages savings of money. Consequently, consumption and demand decrease. Moreover, investment and net export go down. Inversely, lower interest rate stimulates investment and net export of an economy. The short-term and long-term lower interest rate decreases the amount of repayable loans, which also bolster the RMG export. Higher interest rate attracts foreign investors to buy the currency of the country, which attracts more foreign direct investment. Higher demand for the currency creates higher exchange rate by appreciating the currency. Consequently, imports become cheaper comparing with domestically produced goods (Kudlacek, 2009). At the same time, domestic goods of the exporting country 
become more expensive to foreigners, which reduce export volume. Inversely, lower interest rate makes imports more expensive and stimulates the country's export growth.

This study also reveals that the positive growth of female unemployment rate negatively affects the RMG export growth. The RMG industry of Bangladesh has played a positive role towards empowering women. In Bangladesh, approximately $80 \%$ of total RMG workers are women. The relation between unemployment rate and export growth is conditional. The aggregate unemployment rate of a country may increase or decrease whether the export sector has a higher or lower unemployment rate than the export-competing sector (Belensky \& Riker, 2015). The labour intensive and export-oriented RMG sector significantly changes the socio-economic status of Bangladesh by reducing unemployment rate and earning foreign currency (Rahman \& Siddiqui, 2015).

\section{CONCLUSION}

Finally, the positive growth of official exchange rate, inflation rate, real interest rate, and female unemployment rate negatively affect the growth of Bangladesh RMG export. The overall macroeconomic stability of Bangladesh strongly supports the positive growth of RMG export and competitiveness of this sector in world apparel market.

\section{REFERENCES}

Ahmed, H. A., \& Uddin, M. G. S. (2009). Export, imports, remittance and growth in Bangladesh: An empirical analysis. Trade and Development review, 2(2), 79-92. Retrieved from http://tdrju.net/index.php/tdr/article/viewFile/7/23

Al Mamun, K. A., \& Nath*, H. K. (2005). Export-led growth in Bangladesh: a time series analysis. Applied Economics Letters, 12(6), 361-364. https://doi.org/10.1080/13504850500068194

Andersson, A., \& Styf, S. (2010). How does a depreciation in the exchange rate affect trade over time? Unpublished thesis, Jönköping University. Retrieved from http://hj.divaportal.org/smash/get/diva2:305957/FULLTEXT02.pdf.

Aziz, N. (2008). The role of exchange rate in trade balance: Empirics from Bangladesh. University of Birmingham, UK.

Begum, S., \& Shamsuddin, A. F. (1998). Exports and economic growth in Bangladesh. The Journal of Development Studies, 35(1), 89-114. https://doi.org/10.1080/00220389808422556

BGMEA. (2017). Bangladesh Garment Manufacturers and Exporters Association. Retrieved from http://www.bgmea.com.bd/

Belensky, M., \& Riker, D. (2015). Theory and empirical evidence linking international trade to unemployment rate. Journal of International Commerce and Economics. Retrieved from http://www.usitc.gov/journals/jice_home.htm.

Bhattacharya, D., Rahman, M., \& Raihan, A. (2002). Contribution of the RMG Sector to the Bangladesh Economy. CPD Occasional Paper Series, 50(6). Dhaka.

Chow, P. C. (1987). Causality between export growth and industrial development: empirial evidence from the NICs. Journal of development Economics, 26(1), 55-63. https://doi.org/10.1016/0304$\underline{3878(87) 90051-4}$

Cushman, D. O. (1983). The effects of real exchange rate risk on international trade. Journal of International Economics, 15(1-2), 45-63. https://doi.org/10.1016/0022-1996(83)90041-7

Dawson, P. J. (2006). The export-income relationship and trade liberalisation in Bangladesh. Journal of Policy Modeling, 28(8), 889-896. https://doi.org/10.1016/j.jpolmod.2006.04.005 
Di Nino, V., Eichengreen, B., \& Sbracia, M. (2011). Real Exchange Rates, Trade, and Growth: Italy, 1861-2011.

Ferdousi, S. (2009). Interest Rates and Investment Spending Relationship in Bangladesh. Journal of Asian Affairs, 31(2), 5-20.

Gokal, V., \& Hanif, S. (2004). Relationship between inflation and economic growth: Economics Department, Reserve Bank of Fiji.

Hossain, M., \& Karunaratne, N. D. (2004). Trade liberalisation and technical efficiency: evidence from Bangladesh manufacturing industries. Journal of Development Studies, 40(3), 87-114. https://doi.org/10.1080/0022038042000213210

Hossain, S. A., \& Islam, K. A. (2015). The Relationship of the Macroeconomic Variables with the Growth of Garment Industry in Bangladesh. Global Disclosure of Economics and Business, 4(1), 63-78.

Hossain, M. A., \& Alauddin, M. (2005). Trade liberalization in Bangladesh: the process and its impact on macro variables particularly export expansion. The Journal of Developing Areas, 39(1), 127-150. https://doi.org/10.1353/jda.2005.0035

International Trade Center (ITC). (2017). Retrieved July 12, 2017, from http://www.trademap.org/Index.aspx data retrieved

Kabir Hassan, M., \& Tufte, D. R. (1998). Exchange rate volatility and aggregate export growth in Bangladesh. Applied Economics, 30(2), 189-201. https://doi.org/10.1080/000368498325994

Khan, Z. R., \& Rodrigues, G. (2015). Human before the garment: Bangladesh tragedy revisited. Ethical manufacturing or lack thereof in garment manufacturing industry. World Journal of Social Sciences, $\quad 5(1) . \quad 22 \quad-\quad 235 . \quad$ Retrieved from http://www.wjsspapers.com/static/documents/January/2015/2_Zeenath.pdf

Kudlacek, S. (2009). The interest rate and related macroeconomic variables. Finance and Economics, $1-13 . \quad$ Retrieved from https://university.akelius.com/library/pdf/the_intere_kudlacek_s0904.pdf

Mikic, M., \& Gilbert, J. (2008). Trade Statistics in Policymaking-A handbook of commonly used trade indices and indicators: United Nations ESCAP.

Muktadir-Al-Mukit, D., \& Shafiullah, A. (2014). Export, Import And Inflation: A Study on Bangladesh. Amity Global Business Review, 9.

Rahman, M. H., \& Siddiqui, S. A. (2015). RMG: prospect of contribution in economy of Bangladesh. International Journal of Scientific and Research Publications, 5(9), 1-8. Retrieved from http://www.ijsrp.org/research-paper-0915/ijsrp-p45100.pdf

Reza, A. K., Islam, M. S., \& Shimu, A. A. (2017). Green Industry in Bangladesh: An Overview. Environmental Management and Sustainable Development, 6(2), 124-143. https://doi.org/10.5296/emsd.v6i2.11027

Raza, A., Larik, A., \& Tariq, M. (2013). Effects of Currency Depreciation on Trade Balances of Developing Economies: A Comprehensive Study on South Asian Countries. IOSR Journal of Humanities And Social Science, 14(6), 101-106. Retrieved from http://www.iosrjournals.org/iosr-jhss/papers/Vol14-issue6/K0146101106.pdf

Semuel, H., \& Teddy, S. D. (2014). Analysis of the Effect of Inflation, Interest Rates, and Exchange Rates on Gross Domestic Product (GDP) in Indonesia. Petra Christian University.

Shimu, A. A., \& Islam, M. S. (2016). The Prospect of the Readymade Garments Sector in Bangladesh: Result from Trend Analysis. American Journal of Trade and Policy, 3(2), 45-54. http://dx.doi.org/10.18034/ajtp.v3i2.864

World Bank. (2017). Retrieved July 12, 2017, from https://data.worldbank.org/country/bangladesh 


\section{AUTHORS' SHORT BIOGRAPHIES}

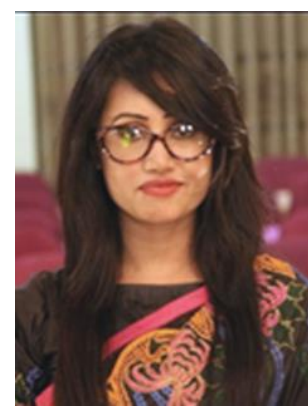

Afroza Ahammed Shimu is currently a Senior Assistant Secretary in Research \& Development Department, Bangladesh Knitwear Manufacturers and Exporters Association (BKMEA), Bangladesh. She has been conducting research work on promoting trade potentialities, different development issues and policy development framework regarding the development of Bangladesh ready-made garment sector. She holds the title of "Master Trainer" recognized by International Training Centre (ITC), Turin, Italy. Her research interests are macroeconomics, development economics, gender studies, and international trade. She has published three research articles in different international journals.

Ms. Shimu earned the degree of MSS in Economics (with distinction) from Shahjalal University of Science \& Technology, Sylhet. She was awarded a university scholarship, and a scholarship of directorate of secondary and higher secondary education.

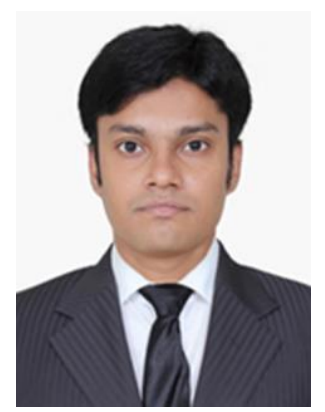

Md. Shahidul Islam is a Senior Assistant Secretary of Bangladesh Knitwear Manufacturers and Exporters Association (BKMEA), Bangladesh. He is also an adjunct research fellow of Bangladesh Institute of Social Research (BISR) Trust, Bangladesh.

He received the degree of MSS (thesis) from Shajalal University of Science and Technology. He is currently studying for MPhil at the University of Dhaka. He has received the grants of the University Grants Commission of Bangladesh, Ministry of planning, Bangladesh Institute of Development Studies (BIDS), Bangladesh Institute of Social Research Trust (BISRT), Institute of Cultural and Development Research (ICDR). His research interests are social capital, reproductive health, migration and internal trade. He has published more than 20 research articles in international journals.

E-mail: shahidulsoc@gmail.com

ORCID iD: https://orcid.org/0000-0002-9351-243X 